\title{
Studies on Graded levels of Lignite flyash on yield and its contributing characters in sorghum (sorghum bicolor)
}

\author{
D. Kumarimanimuthuveeral, ${ }^{1}$ \\ Assistant Professor, Department of Agronomy, \\ Annamalai University, Chidambaram, Tamil Nadu.
}

\begin{abstract}
Two investigations were carried out to study the combined effect of agro industrial wastes such as pressmud, a waste from sugar mill and lignite fly ash a by product from thermal unit on sorghum, cv.Co-1 during 2011 and 2012. The study revealed that lignite fly ash@10t ha $a^{-1}+$ pressmud @12.5t ha $a^{-1}$ significantly superior in all growth, yield and yield parameters of sorghum. Significantly higher yield per hectare (3.95t

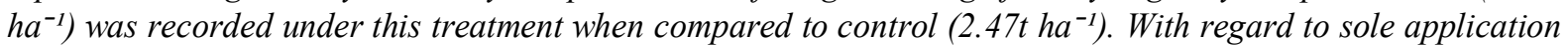
LFA,LFA@5tha $a^{-1}$ exerted other levels (10,15 and 20t ha-1).From this study it was suggested that LFA@ $10 t \mathrm{~h}^{-1}$ with press mud and RDF had remarkable effect on sorghum crop for both the seasons.
\end{abstract}

Key words: Lignite fly ash (LFA), pressmud.

\section{Introduction}

Sorghum is one of the most important cereal crop grown in kharif and Rabi season in various part of India. Numerous sorghum species are used for food (as grain and sorghum syrup or sorghum molasses) fodder, the production of alcoholic beverages as well as bio fuels. It is drought tolerant and staple or one of the staples for poor and rural people. It is the fifth most important cereal crop grown in the world.

Large potential of industrial wastes exists in India. Industrialization is not only consumed agricultural lands but accumulation of large quantities of wastes due to the phenomenal growth of industries pose a serious threat to the environment. The industrial by products which are otherwise known as wastes, contain an array of plant nutrients and these nutrients are dumped unutilized. It may be feasible to use relatively larger quantities of these wastes as manures / amendments for crop production after proper treatment or combination ( Kumari mani muthu veeral,2009).

The application of lignite fly ash on agricultural land has widely been evaluated. In order to improve the $\mathrm{N}$ and $\mathrm{P}$ status of crop and soil, the use of organic manure can be explored(Kumari mani muthu veeral,2008).But whether these manures will be able to perform well in presence of lignite fly ash needs to be evaluated. Keeping this in mind, a field experiment was conducted to examine the compatibility of lignite fly ash with pressmud and RDF in the Sorghum productivity.

\section{Materials And Methods}

Field experiments were conducted in the farmer's field Neyveli during April, 2011 and January, 2012 in Sorghum Co 1. The weathered lignite fly ash was collected from Neyveli Lignite Corporation Ltd., Neyveli. The press mud was collected from the sugar mill in Sethiathope, Cuddalore district. The experiments comprised of ten treatments viz., $\mathrm{T}_{1}-$ Control, $\mathrm{T}_{2}-$ Farmer's practice, $\mathrm{T}_{3}-$ Lignite fly ash @ $5 \mathrm{tha}^{-1}+\mathrm{RDF}, \mathrm{T}_{4}-$ Lignite fly ash@ $5 \mathrm{tha}^{-1}+$ Press mud + RDF, T 5 - Lignite fly ash@10 $\mathrm{tha}^{-1}+\mathrm{RDF}, \mathrm{T}_{6}$ - Lignite fly ash @ $10 \mathrm{tha}^{-1}$ + Press mud + RDF, T 7 - Lignite fly ash @ $15 \mathrm{t} \mathrm{ha}^{-1}+\mathrm{RDF}, \mathrm{T}_{8}$ - Lignite fly ash @ $15 \mathrm{tha}^{-1}+$ Press mud + RDF, $T_{9}$ - Lignite fly ash@ @ $20 \mathrm{t} \mathrm{ha}^{-1}+\mathrm{RDF}, \mathrm{T}_{10}$ - Lignite fly ash@20 $\mathrm{t} \mathrm{ha}^{-1}+$ Press mud + RDF. Experiments were conducted in Randomized block design with three replications. Standard agronomic practices were adopted. Data on growth, yield components, yield and economics were recorded.

\section{Results And Discussion}

The results presented in Table 1 revealed that there was significant difference with respect to growth parameters of Sorghum crop during 2010. Significant increase in plant height at harvest $(198 \mathrm{~cm})$ was noticed at 10t LFA ha ${ }^{-1}$ with pressmud and RDF compared to $5 \mathrm{t}, 15 \mathrm{t}$, and $20 \mathrm{t} \mathrm{LFA} \mathrm{ha}{ }^{-1}$ with and without pressmud. This may be due to the supply of essential nutrients to the sorghum crop at all the stages by the combined application of LFA and pressmud. This was online with the findings of Kumari mani muthu veeral, (2009) as combined

\footnotetext{
${ }^{1}$ Principle Investigator, UGC Major Lignite fly ash project
} 
application of LFA and pressmud enhanced the growth parameters of maize because of the release of nutrient at the critical stage of the crop plants.

With regard to yield and yield parameters, number of ear heads plant ${ }^{-1}$, grains per head and grain yield were significantly enhanced with the application of LFA@10 $\mathrm{ha}^{-1}$ with pressmud and RDF by recording 14, 1188 and 3.95 $\mathrm{th}^{-1}$ respectively, when compared to sole application of LFA @ 10t ha $\mathrm{ha}^{-1}\left(8,990\right.$ and 3.3t ha $\mathrm{h}^{-1}$ respectively). The same trend was followed in summer 2011 in growth and yield parameters in sorghum (Table 2). The increase in seed yield might be due to increase in organic matter content of the soil and lignite fly ash together with pressmud could be successfully used as a fertility boosting resource material in the crop production as supported by Kumari mani muthu veeral,2008.

\section{References}

[1]. Kumari mani muthu veeral, D.2009. Utilization of industrial wastes in maize based cropping system. TNSCST. Stu. pro. rep. Annamalai Univ.

[2]. Kumari mani muthu veeral, D.2008. Recycling of industrial wastes in groundnut based cropping system. TNSCST. Stu. pro. rep . Annamalai Univ.

Table 1. Effect of LFA, press mud and RDF on Growth, yield and yield attributes in sorghum (2010)

\begin{tabular}{|c|c|c|c|c|c|c|c|}
\hline Treatment & $\begin{array}{c}\text { Plant } \\
\text { height } \\
\text { (cm) }\end{array}$ & $\begin{array}{c}\text { Leaf } \\
\text { area } \\
\text { index } \\
\end{array}$ & $\begin{array}{c}\text { Dry matter } \\
\text { production } \\
\text { g/plant }\end{array}$ & $\begin{array}{l}\text { No. of ear } \\
\text { heads } / \mathbf{m}^{2}\end{array}$ & $\begin{array}{c}\text { Grain } \\
\text { number/ head }\end{array}$ & $\begin{array}{c}\text { Test } \\
\text { weight }\end{array}$ & $\begin{array}{c}\text { Grain } \\
\text { yield } \\
\left(\text { tha }^{-1}\right) \\
\end{array}$ \\
\hline$T_{1}$ & 140 & 2.7 & 6.3 & 7 & 960 & 24.01 & 2.4 \\
\hline $\mathbf{T}_{2}$ & 162 & 3.03 & 7 & 11 & 1073 & 24.12 & 3.7 \\
\hline $\mathbf{T}_{3}$ & 160 & 3.2 & 6.9 & 19 & 1000 & 24.10 & 3.5 \\
\hline $\mathbf{T}_{4}$ & 189 & 3.7 & 7.9 & 13 & 1170 & 24.40 & 3.81 \\
\hline $\mathbf{T}_{5}$ & 157 & 3.1 & 6.8 & 8 & 990 & 24.08 & 3.3 \\
\hline$T_{6}$ & 194 & 3.8 & 8.2 & 14 & 1188 & 24.46 & 3.95 \\
\hline $\mathbf{T}_{7}$ & 153 & 3 & 6.7 & 7 & 980 & 24.06 & 3.0 \\
\hline$T_{8}$ & 173 & 3.5 & 7.7 & 11 & 1155 & 24.35 & 3.63 \\
\hline $\mathbf{T}_{9}$ & 150 & 2.9 & 6.5 & 6 & 970 & 24.04 & 2.9 \\
\hline $\mathbf{T}_{\mathbf{1 0}}$ & 165 & 3.4 & 7.3 & 10 & 1124 & 24.30 & 3.5 \\
\hline SED & 3.2 & 0.4 & 1.0 & 2.2 & 45 & N.S & 1.2 \\
\hline $\mathrm{P}=\mathrm{CD}=-.05$ & 6.4 & 0.8 & 2.0 & 4.4 & 90 & N.S & 2.4 \\
\hline
\end{tabular}

Table 2. Effect of LFA, press mud and RDF on Growth, yield and yield attributes in sorghum (2011)

\begin{tabular}{|c|c|c|c|c|c|c|c|}
\hline Treatment & $\begin{array}{l}\text { Plant height } \\
(\mathrm{cm})\end{array}$ & $\begin{array}{l}\text { Leaf area } \\
\text { index }\end{array}$ & $\begin{array}{c}\text { Dry matter } \\
\text { production } \\
\text { g/plant }\end{array}$ & $\begin{array}{l}\text { No .of ear } \\
\text { heads } / \mathbf{m}^{2}\end{array}$ & $\begin{array}{c}\text { Grain } \\
\text { number/ head }\end{array}$ & Test weight & $\begin{array}{c}\text { Grain yield } \\
\left(\text { tha }^{-1}\right)\end{array}$ \\
\hline $\mathbf{T}_{1}$ & 142 & 2.72 & 6.9 & 9 & 973 & 24.01 & 2.7 \\
\hline $\mathbf{T}_{2}$ & 165 & 3.04 & 7.7 & 13 & 1088 & 24.13 & 4.0 \\
\hline$T_{3}$ & 162 & 3.3 & 7.5 & 22 & 1021 & 24.11 & 3.8 \\
\hline$T_{4}$ & 192 & 3.74 & 8.2 & 15 & 1188 & 24.42 & 4.2 \\
\hline$T_{5}$ & 160 & 3.13 & 7.1 & 11 & 1007 & 24.09 & 3.5 \\
\hline$T_{6}$ & 197 & 3.82 & 8.5 & 17 & 1204 & 24.47 & 4.3 \\
\hline $\mathbf{T}_{7}$ & 156 & 3.2 & 7.1 & 10 & 997 & 24.07 & 3.2 \\
\hline$T_{8}$ & 177 & 3.52 & 8.0 & 13 & 1176 & 24.36 & 3.8 \\
\hline$T_{9}$ & 153 & 2.92 & 6.8 & 9 & 987 & 24.04 & 3.2 \\
\hline$T_{10}$ & 168 & 3.45 & 7.6 & 12 & 1138 & 24.4 & 3.7 \\
\hline SED & 3.0 & 0.41 & 1.1 & 2.3 & 51 & N.S & 1.3 \\
\hline $\mathrm{P}=\mathrm{CD}=-.05$ & 6.1 & 0.82 & 2.2 & 4.6 & 102 & N.S & 2.6 \\
\hline
\end{tabular}

